\title{
ESSENTIAL AND TRACE ELEMENT CONTENTS OF MORINGA OLEIFERA FROM AKURE AND ILE-IFE IN THE SOUTH WESTERN NIGERIA
}

\author{
Aborisade, C. A., ${ }^{1 *}$ Ibitoye, F. I., , Sogeke, O. I., ${ }^{1}$ Obiajunwa, E. I., ${ }^{2}$ Balogun, F. A. ${ }^{2}$ \\ 1Department of Physics and Engineering Physics, Obafemi Awolowo University, Ile-Ife. Nigeria. \\ 2Center for Energy Research and Development, Obafemi Awolowo University, Ile-Ife. Nigeria. \\ *Corresponding Author email. caborisade@yahoo.com, (+234)8037007900)
}

(Received: $5^{\text {th }}$ December, 2018; Accepted: $28^{\text {th }}$ February, 2019)

\section{ABSTRACT}

Particle Induced X-ray Emission technique has been employed in the determination of essential and trace elements in Moringa oleifera leaves and seeds from two sites in South Western Nigeria. Sixteen elements $(\mathrm{Na}$, $\mathrm{Mg}, \mathrm{Al}, \mathrm{Si}, \mathrm{P}, \mathrm{S}, \mathrm{Cl}, \mathrm{K}, \mathrm{Ca}, \mathrm{Mn}, \mathrm{Fe}, \mathrm{Cu}, \mathrm{Zn}, \mathrm{Rb}, \mathrm{Sr}$ and $\mathrm{Ba}$ ) were detected and quantified. Rb and Ba were detected only in the leaves, while $\mathrm{Al}$ and $\mathrm{Na}$ were found only in the seeds. The leaves have higher concentration of $\mathrm{K}$ $(17053.90 \pm 56.28 \mathrm{ppm})$ whereas the element with highest concentration in the seeds was $\mathrm{S}(5474 \pm 44.35 \mathrm{ppm})$. The results show that the plant contains many elements of vital importance for human metabolism, diseases prevention and healing.

Keywords: Moringa oleifera, leaves, seeds and elements.

\section{INTRODUCTION}

It is a known fact that man requires both organic and inorganic nutrients for his biochemical processes (i.e. heterotrophic creature). Man gets most of his nutritional requirements through his diet and adequate amount of these elements is good for human health. There are studies from around the World that illustrate how wild resources often form an integral part of our livelihood (Scoones I.et al, 1992). It has been estimated by the World Health Organization (WHO) that up to $80 \%$ of people are still relying primarily on traditional remedies such as herbs for their medicines (Ekor M., 2014). The variation in composition of these natural resources varies from one locality to another leading to deficiencies and excesses depending on the availability and quantity presence. In the last two decades, Moringa oleifera has gained a lot of visibility as a veritable source of anti-oxidant. Moringa oleifera is the most widely cultivated specie of the monogenetic family. Moringa is native to the subHimalayan tracts of India, Pakistan, Bangladesh and Afghanistan. It is now widely cultivated and has become domesticated in many locations in the tropics including Nigeria. The medicinal value of this plant is due to its essential and trace element content. Every part of Moringa oleifera has medicinal properties and is commercially exploitable for the development of medicinal and industrial by-products (Miracle Trees, 2014). The presence of Moringa oleifera tree in a farm provides bio-diverse environment which can be beneficial for both the owner of the farm and the surrounding eco-system (Foidl N.et al., 2009). The antioxidant properties of the constituents of Moringa oleifera, is associated with a wide range of amphipathic molecules that are broadly referred to as polyphenolic compounds responsible for disease prevention or control (Demiray S. et al., 2009). The leaves, fruits, flowers, and immature pods of this tree are edible; they are used as a highly nutritive vegetable in many countries, particularly in India, Pakistan, the Philippines, Hawaii, and some African nations (Anhwange B. A. et al., 2004, Anwar F, et al., 2005 and Oluduro 2012). Work has been done on the chemical composition and the nutritional values of Moringa oleifera (Yameogo C. W et al., 2011). It has been reported that the leaves contain trace elements such as iron, zinc, magnesium, and selenium that are essential to human health (Gyamfi E. T. et al., 2011). It has also been reported that the level of elements in Moringa depends on the type of soil on which the plant was cultivated, the variable uptake of minerals by the plant materials and variable agro-ecologies of the different regions (Anjorin T. S. et al., 2010). In Nigeria, the mineral composition of the lamina, 
petiole, seed pod, seed shell, seed kernel powder and seed kernel oil of Moringa oleifera from two regions, of Abuja, were investigated. The results confirmed that there are variations in macro and trace minerals in Moringa leaves, pods and seeds from different locations (Anjorin T. S. et al., 2010). The presence of heavy metals in soil and vegetable grown in some area in Nigeria has been established and the concentration of these heavy metals varies from one place to another (Mohammed S. S. et al., 2015 and Abdulmojeed O. L.et al. 2011).

In Nigeria every part of this plant is use as food for human being and livestock, herbs medicine and some other beneficial property. Millions of people in the Tropics especially Nigeria have been consuming Moringa plants recently, for its medicinal values. Both children and adult have ingested Moringa and used it for other purposes. This study is necessary and is intended to analyse the elemental constituent and nutritional potential of the Moringa oleifera plants from the two different locations in South Western Nigeria so as to educate the public especially the rural area of Nigerian on reasons to or not to consume Moringa.

\section{MATERIALS AND METHODS}

Particle Induced X-ray Emission (PIXE) technique was performed using a $2.5 \mathrm{MeV}$ proton beam obtained from Center for Energy Research and Development (CERD) ion beam analysis (IBA) facility. The facility is centered on a NEC 5SDH 1.7MV Pelletron Accelerator, equipped with a radiofrequency charge exchange ion source. The ion source is equipped to provide proton and helium ions. The end-station consists of an Aluminium chamber of about $150 \mathrm{~cm}$ diameter and $180 \mathrm{~cm}$ height. The chamber has a sample ladder that can carry 11 (eleven) $13 \mathrm{~mm}$ diameter samples. The end-station has a turbo pump and a variable beam collimator to regulate beam size, and an isolation value. Control was affected by analysing the (NIST 1515). The same standard was employed in the determination of the $\mathrm{H}$-value which was eventually used in analysed samples. The measurements were carried out with a beam spot of $4 \mathrm{~mm}$ in diameter and a low beam current of 3-6 nA. The irradiation was for about 10-20 minutes. A Canberra Si(Li) detector Model ESLX 30-150, beryllium thickness of $25 \mu \mathrm{m}$, with full width half maximum (FWHM) of $150 \mathrm{eV}$ at 5.9 $\mathrm{keV}$, with the associated pulse processing electronics, and a Canberra Genie 2000 (3.1) MCA card interfaced to a PC were used for the X-rays data acquisition. The PIXE set-up was calibrated using some pure element standards and NIST geological standard, NBS278.

The computer code GUPIXWIN was used for the analysis of the PIXE data. GUPIXWIN is a versatile software package for fitting PIXE spectra from thin, thick, intermediate and layered specimens. It extracts peak intensities and converts these to concentrations via the $\mathrm{H}$-value standardisation method. It provides a non-linear least square fitting of the spectrum, together with subsequent conversion of the fitted X-ray peak intensities into elemental concentrations (Campebell J. L. et al., 2018, Campbell J. L. et al., 2016 and Russell J. L. et al., 2018).

PIXE is a powerful yet non-destructive elemental analysis technique now used routinely by geologists, archaeologists, art conservators and others to help answer questions of provenience, dating and authenticity.

\section{Sample Collection}

Samples were collected from two (2) different locations. The first location was Town Planning Way Shagari Village, Akure, the most populated town in Ondo State and the second location was the Senior Staff Quarters of the OAU, Ile-Ife, the most populated town in Osun State, both in South Western Nigeria. The samples collected were Moringa oleifera leaves and seeds. Samples were collected from ten (10) different areas in each of the two locations. Some leaves and seed pods were from matured Moringa oleifera trees and were packed in well labelled poly-ethyne bags.

\section{Sample Preparation}

Each sample was washed extensively in distilled water in order to remove superficial contamination. The leaves and seeds were spread on trays to dry under room temperature.

In order to improve the binding of the pellet and 
to make the surface conducting, the dried samples were ground in an agate mortar and mixed with $10 \%$ by weight of ultra-pure graphite powder prepared into Thick pellets of $13 \mathrm{~mm}$ diameter without binder. These samples were taken to the accelerator hall at the CERD Obafemi Awolowo
University, Ile-Ife, for PIXE analysis.

\section{RESULTS AND DISCUSSION}

The result obtained for the leaves and seeds samples from the two locations are given in the tables 1 to 3 below.

Table 1: The Elemental Concentrations in the Moringa oleifera Leaves.

\begin{tabular}{|l|c|c|}
\hline Element & $\begin{array}{c}\text { Concentration in Akure sample } \\
(\mathbf{p p m})\end{array}$ & $\begin{array}{c}\text { Concentration in OAU sample } \\
(\mathbf{p p m})\end{array}$ \\
\hline $\mathrm{Mg}$ & $3837.3 \pm 223.3$ & $3538.8 \pm 206.0$ \\
\hline $\mathrm{Si}$ & $1475.0 \pm 42.5$ & $1332.4 \pm 37.2$ \\
\hline $\mathrm{P}$ & $2661.2 \pm 72.4$ & $1808.7 \pm 62.0$ \\
\hline $\mathrm{S}$ & $8772.6 \pm 60.5$ & $5072.6 \pm 47.7$ \\
\hline $\mathrm{Cl}$ & $1412.9 \pm 39.7$ & $1188 \pm 30.7$ \\
\hline $\mathrm{K}$ & $17053.9 \pm 56.2$ & $16908.4 \pm 50.7$ \\
\hline $\mathrm{Ca}$ & $14467.7 \pm 63.7$ & $12567.7 \pm 61.6$ \\
\hline $\mathrm{Mn}$ & $71.3 \pm 5.4$ & $32.6 \pm 5.1$ \\
\hline $\mathrm{Fe}$ & $113.5 \pm 4.3$ & $329.7 \pm 6.6$ \\
\hline $\mathrm{Cu}$ & $3.7 \pm 1.7$ & $5.0 \pm 1.7$ \\
\hline $\mathrm{Zn}$ & $15.3 \pm 2.4$ & $11.4 \pm 2.2$ \\
\hline $\mathrm{Rb}$ & $29.2 \pm 14.3$ & $25.1 \pm 10.8$ \\
\hline $\mathrm{Sr}$ & $\mathrm{ND}$ & $89.2 \pm 20.8$ \\
\hline $\mathrm{Ba}$ & $\mathrm{ND}$ & $662.0 \pm 162.9$ \\
\hline
\end{tabular}

ND means not detectable.

Table 2: The Elemental Concentration in Moringa oleifera Seeds.

\begin{tabular}{|l|c|c|}
\hline Element & $\begin{array}{c}\text { Concentration in Akure sample } \\
(\mathbf{p p m})\end{array}$ & $\begin{array}{c}\text { Concentration in OAU sample } \\
(\mathbf{p p m})\end{array}$ \\
\hline $\mathrm{Mg}$ & $740 \pm 94.2$ & $735.3 \pm 90.9$ \\
\hline $\mathrm{Si}$ & $320.1 \pm 19.8$ & $351.8 \pm 18.99$ \\
\hline $\mathrm{P}$ & $1401.3 \pm 35.9$ & $1229.4 \pm 34.8$ \\
\hline $\mathrm{S}$ & $5474 \pm 44.4$ & $4934.1 \pm 41.9$ \\
\hline $\mathrm{Cl}$ & $119.7 \pm 29.8$ & $143.3 \pm 28.0$ \\
\hline $\mathrm{K}$ & $3708.3 \pm 33.0$ & $3534.2 \pm 32.2$ \\
\hline $\mathrm{Ca}$ & $394.0 \pm 14.2$ & $310.0 \pm 13.1$ \\
\hline $\mathrm{Mn}$ & $6.6 \pm 1.4$ & $\mathrm{ND}$ \\
\hline $\mathrm{Fe}$ & $26.1 \pm 2.0$ & $20.8 \pm 1.6$ \\
\hline $\mathrm{Cu}$ & $\mathrm{ND}$ & $2.5 \pm 1.0$ \\
\hline $\mathrm{Zn}$ & $5.2 \pm 1.4$ & $2.4 \pm 1.1$ \\
\hline $\mathrm{Rb}$ & $\mathrm{ND}$ & $\mathrm{ND}$ \\
\hline $\mathrm{Sr}$ & $10.0 \pm 9.2$ & $\mathrm{ND}$ \\
\hline $\mathrm{Ba}$ & $\mathrm{ND}$ & $\mathrm{ND}$ \\
\hline $\mathrm{Al}$ & $73.4 \pm 14.3$ & $87.4 \pm 13.7$ \\
\hline $\mathrm{Na}$ & $\mathrm{ND}$ & $8.2 \pm 5.4$ \\
\hline
\end{tabular}

ND means not detectable. 
Dietary Reference Intakes (DRI) is the general term for a set of reference values used to plan and assess nutrient intakes of healthy people. The values vary by age and gender. It includes
Recommended Dietary Allowance (RDA) that is, average daily level of intake sufficient to meet the nutrient requirements of nearly all health people. The values are presented in table 3 and 4 .

Table 3: Comparing the minerals and micronutrients from leaves and seeds with the Recommended Dietary Allowance (RDA).

\begin{tabular}{|c|c|c|c|c|c|}
\hline \multirow{2}{*}{ Element } & \multicolumn{2}{|c|}{$\begin{array}{c}\text { Concentration (mg) from } \\
\text { leaves }\end{array}$} & \multicolumn{2}{c|}{ Concentration (mg) from } & RDA* \\
\cline { 2 - 6 } & Akure & OAU & Akure & OAU & $\begin{array}{c}\text { Standard } \\
\text { (mg/d) }\end{array}$ \\
\hline $\mathrm{Mg}$ & 383.7 & 353.9 & 74.0 & 73.5 & $30-420$ \\
\hline $\mathrm{Si}$ & 147.5 & 133.2 & 32.0 & 35.2 & \\
\hline $\mathrm{P}$ & 266.1 & 180.9 & 140.1 & 122.9 & $100-1250$ \\
\hline $\mathrm{S}$ & 877.3 & 507.3 & 547.5 & 493.4 & - \\
\hline $\mathrm{Cl}$ & 141.3 & 118.9 & 12.0 & 14.3 & $180-2,300$ \\
\hline $\mathrm{K}$ & 1705.4 & 169.1 & 370.8 & 353.4 & $400-5,100$ \\
\hline $\mathrm{Ca}$ & 1446.8 & 1256.8 & 39.4 & 31.0 & $1,000-3,000$ \\
\hline $\mathrm{Mn}$ & 7.1 & 3.3 & 7.0 & - & $0.003-11$ \\
\hline $\mathrm{Fe}$ & 11.4 & 33.0 & 2.6 & 2.1 & $0.27-27$ \\
\hline $\mathrm{Cu}$ & 4.0 & 5.0 & 0 & 3.0 & $0.2-10$ \\
\hline $\mathrm{Zn}$ & 1.5 & 1.1 & 5.0 & 2.0 & $2-13$ \\
\hline $\mathrm{Rb}$ & 2.9 & 2.5 & - & - & - \\
\hline $\mathrm{Sr}$ & - & 2.9 & 1.0 & - & - \\
\hline $\mathrm{Ba}$ & - & 66.2 & - & 6.2 & - \\
\hline $\mathrm{Al}$ & - & - & 7.3 & 8.4 & - \\
\hline $\mathrm{Na}$ & - & - & - & 8.2 & $120-1,500$ \\
\hline
\end{tabular}

*(Ross A. A. et al., 2011) 
Table 4: Recommended Dietary Allowances for minerals and micronutrients in $\mathrm{mg} / \mathrm{d}$ (Ross A. A. et al., 2011).

\begin{tabular}{|c|c|c|c|c|c|c|c|c|c|c|}
\hline $\begin{array}{c}\text { Age } \\
\text { (year) }\end{array}$ & $\mathbf{C a}$ & $\mathbf{P}$ & $\mathbf{C u}$ & $\mathbf{M g}$ & $\mathbf{F e}$ & $\mathbf{Z n}$ & $\mathbf{C l}$ & $\mathbf{M n}$ & $\mathbf{K}$ & $\mathbf{N a}$ \\
\hline \multicolumn{10}{|c|}{ Infants } \\
\hline $0-0.5$ & 1,000 & 100 & - & 30 & 0.27 & 2 & 180 & 0.003 & 400 & 120 \\
\hline $0.5-1$ & 1,500 & 270 & - & 75 & 11 & 3 & 570 & 0.60 & 700 & 370 \\
\hline \multicolumn{10}{|c|}{ Children } \\
\hline $1-3$ & 2,500 & 460 & 1 & 80 & 7 & 3 & 1,500 & 2 & 3,000 & 1,000 \\
\hline $4-8$ & 2,500 & 500 & 3 & 130 & 10 & 5 & 1,900 & 3 & 3,800 & 1,200 \\
\hline \multicolumn{10}{|c|}{ Male } \\
\hline $9-13$ & 3,000 & 1,250 & 5 & 240 & 8 & 8 & 2,300 & 6 & 4,500 & 1,500 \\
\hline $14-18$ & 3,000 & 1,250 & 8 & 410 & 11 & 11 & 2,300 & 9 & 4,700 & 1,500 \\
\hline $19-30$ & 2,500 & 700 & 10 & 400 & 8 & 11 & 2,300 & 11 & 4,700 & 1,500 \\
\hline $31-50$ & 2,500 & 700 & 10 & 420 & 8 & 11 & 2,300 & 11 & 4,700 & 1,500 \\
\hline $51-70$ & 2,000 & 700 & 10 & 420 & 8 & 11 & 2,000 & 11 & 4,700 & 1,300 \\
\hline$>70$ & 2,000 & 700 & 10 & 420 & 8 & 11 & 1,800 & 11 & 4,700 & 1,200 \\
\hline \multicolumn{10}{|c|}{ Female } \\
\hline $9-13$ & 3,000 & 1,250 & 5 & 240 & 8 & 8 & 2,300 & 6 & 4,500 & 1,500 \\
\hline $14-18$ & 3,000 & 1,250 & 8 & 360 & 15 & 9 & 2,300 & 9 & 4,700 & 1,500 \\
\hline $19-30$ & 2,500 & 700 & 10 & 310 & 18 & 8 & 2,300 & 11 & 4,700 & 1,500 \\
\hline $31-50$ & 2,500 & 700 & 10 & 320 & 18 & 8 & 2,300 & 11 & 4,700 & 1,500 \\
\hline $51-70$ & 2,000 & 700 & 10 & 320 & 8 & 8 & 2,000 & 11 & 4,700 & 1,300 \\
\hline$>70$ & 2,000 & 700 & 10 & 320 & 8 & 8 & 1,800 & 11 & 4,700 & 1,200 \\
\hline \multicolumn{10}{|c|}{ Pregnancy } \\
\hline $14-18$ & 3,000 & 1,250 & 8 & 400 & 27 & 12 & 2,300 & 9 & 4,700 & 1,500 \\
\hline $19-30$ & 2,500 & 700 & 10 & 350 & 27 & 11 & 2,300 & 11 & 4,700 & 1,500 \\
\hline $30-50$ & 2,500 & 700 & 10 & 360 & 27 & 11 & 2,300 & 11 & 4,700 & 1,500 \\
\hline \multicolumn{10}{|c|}{ Lactation } \\
\hline $14-18$ & 3,000 & 1,250 & 8 & 360 & 10 & 13 & 2,300 & 9 & 5,100 & 1,500 \\
\hline $19-30$ & 2,500 & 700 & 10 & 310 & 9 & 12 & 2,300 & 11 & 5,100 & 1,500 \\
\hline $30-50$ & 2,500 & 700 & 10 & 320 & 9 & 12 & 2,300 & 11 & 5,100 & 1,500 \\
\hline
\end{tabular}

From tables 1 and 2 the concentration of the elements in Moringa oleifera leaves and seeds from the two locations have no significant different. Trace amount of $\mathrm{Al}, \mathrm{Na}$ and $\mathrm{Cu}$ were detected in the seeds from OAU but not detectable in the seed from Akure. Trace of Sr and $\mathrm{Mn}$ were detected in the seeds from Akure but not detectable in the seeds from OAU. When compared to recommended dietary allowances in tables 3 and 4, the minerals from the two locations are within the recommended allowance.

The result shows that Moringa oleifera leaves has higher concentration of elements than the seeds contrary to the general belief that Moringa oleifera seed are richer in nutritional minerals. The result is in agreement with the finding of Maida et al. (Maida A. et al., 2005). Also,the resultsarein agreements with thosefrom other works because the elements with high concentrationin the leaves arealso have highconcentration in the seed that were analysed (Ahwange B. A. et al., 2004; Anwar F. et al., 2005; Oluduro A. O., 2012;Gyamfi E. T. I. et al., 2011 and Anjorin T. S., 2010) this is because the level of elements in Moringa depends on the type of soil on which the plant was cultivated, the variable uptake of minerals by the plant materials and variable agro-ecologies of the different regions(Anjorin T. S. et al., 2010). But there is no significant difference in the concentration of the element between the samples in the two locations as opposed to Maida et al (Maida A. et al., 2005). The result confirmed that there are variations in macro and trace minerals in Moringa leaves and seeds (Anjorin T. S. et al., 2010). 
Elements such as carbon, nitrogen, phosphorous, iron, sodium, magnesium, silicon and potassium are required in substantial amounts, while copper, manganese and cobalt are required in smaller amount (micronutrients) from human health. The samples present high level of calcium that is beneficial to human body because it is an essential element in the development of our skeletal structure, blood clotting, verve and muscular functions. It regulates cation balance between cells and milieu and acts as enzyme cofactor.Also, magnesium that is important in ionic balance and enzyme cofactor is of high concentration in all the samples analysed. Another element found in large quantity is potassium $(\mathrm{K})$, a major intracellular cation. This is known to be involved in ionic balance and maintenance of electrochemical potential across cell membranes and prommotion of protein synthesis. Iron $(\mathrm{Fe})$, that is a good component in cytochromes, catalase, haemoglobin, myoglobin and essential for B vitamin synthesis is present in the sample (Wwrtz W., 1972; Spivey-Fox M. R., 1972; Dallman P. R., 1998 and Davies O. A. et al., 2006). The presence of manganese which is essential to arginase and alkaline phosphatase activity in the liver, enzyme cofactors; synthesis of vitamins and calcium metabolism is of good nutritional value. Also, it exerts a catalytic effect on haemoglobin and a cholesterol synthesis. The intake is estimated in the range of $2-7 \mathrm{mg} /$ day, and this limit is not exceeded. Copper that is required for synthesis of haemoglobin and iron-containing enzymes and enzyme component is also present. The dietary copper governs the metabolic fate of cholesterol than the zinc (Murthy I. and Anderson B. M., 1976). Copper deficiency can produce a severe anaemia as well as grey hair. In all the essential and trace elements detected, their concentrations are within the maximum permissible values by the National Agency for Food and Drug Administration and Control's (NAFDAC). Heavy metals such as lead, barium, mercury and cadmium have no essential role in the human body but toxic even at low level are completely absent from all the samples in this work as opposed to what was reported in the samples from Kaduna, Kano and Ebonyi States in the same country but different geographical locations (Mohammed S. A. and Folorunsho J. O., 2015, Abdulmojeed O. L. and Abdulrahman A. A., 2011), and Offor I, et al.,
2014).

\section{CONCLUSIONS}

Moringa Oleifera is found to consist of several trace and major elements of importance to human heath. Products from this plant can therfore serve as health supplements especially in adults. The absence of harmful elements in the moringa oleifera leaves and seeds showed that the product has no potential danger to the consumers. There was slight difference in concentration of the elements found at the two locations, but of obvious difference are phosphorus, sulphur, manganese and iron, these different in concentrations might be from the soil content that varies from one location to another. Our results shows that Moringa oleifera can be useful as mineral suppliment for all age groups.

\section{REFERENCES}

Abdulmojeed O. L., Abdulrahman A. A., (2011). Analysis of heavy metals found in vegetables from some cultivated irrigated gardens in the Kano metropolis, Nigeria. Journal of Environmental Chemistry and Ecotoxicology vol. 3(6), pp. 142-148.

Anhwange B. A., Ajibola V. O., Oniye S. J., (2004); "Chemical studies of seeds of Moringa oleifera and Detariummicrocarpum seeds," Journal of Biological Sciences, vol. 4, no. 6, pp. 711-715,.

Anjorin, T.S., P. Ikokoh and S. Okolo, (2010); Mineral composition of Moringa oleifera leaves, pods and seeds from two regions in Abuja, Nigeria.Int. J. Agric. Biol., 12: 431-434.

Anwar F., Ashraf M., Bhanger M. I., (2005); “Inter provenance variation in the composition of Moringa oleifera oilseeds from Pakistan," Journal of the American Oil Chemists' Society, vol. 82, no. 1, pp. 45-51,.

Campbell J. L., Ganly C. M, Heirwegh C. M Maxwell J. A. (2018); Separation of detector non-linearity issues and multiple ionization satellites in alpha-particle PIXE analysis. Nucl. Instr. Meth. B414, 38-44.

Campbell J. L., Heirwegh C. M., Ganly B. (2016); Non-linearity issues and multiple ionization satellites in the PIXE proton of 
specta from the Martian alpha particle Xray spectrometer. Nuclear Instrumentation Methods B383, 143-151.

Dallman P. R. (1998), Biochemical basis for the manifestations of iron deficiency. Annual Review of nutrition, 6:13-40.

Davies O. A. Aliso M. E., Uyi H. S. (2006); Bioaccumulation of heavy metals in water sediment and periwinkle (Tympanotonusfuscatus van radula) from the Elechi creek, Niger Delta. African Journal of Biotechnology vol. 5(10), pp 968-973.

Demiray S., Pintado M. E., and Castro P. M. L., (2009) "Evaluation of phenolic profiles and antioxidant activities of Turkish medicinal plant: Tiliaargentea, Crataegi folium leaves and Polygonumbistorta roots," World Academy of Science, Engineering and Technology, vol. 54, pp. 312-317,.

Ekor M., (2014); “The growing use of herbal medicines: issues relating to adverse reactions and challenges in monitoring safety," Frontiers in Pharmacology, vol. 4, pp. 1-10.View at Publisher.

Foidl N., Makkar H. P. and Becker K. (2001); The potential of Moringa oleifera for agricultural and industrial uses. In: "The Miracle Tree/ The Multiple Attributes of Moringa" (Ed. Lowell J Fuglie) CTA. USA.

Gyamfi E.T ,I. K, Kwarteng M.O., Ansah A. K., Anim M., Ackah, L. K, Nash O. B. (2011); Effects of processing on Moringa oleifera. Proceedings of the International Academy of Ecology and Environmental Sciences. 1(3-4): 179-185.

Maida Aslam, Farooq Anwar, Raziya Nadeem, Umer Rashid, T.G. Kazi and M. Hadeem, (2005); Mineral Composition of Moringa oleifera Leaves and Pods from Different Regions of Pujab, Pakistan. Asian Journal of Plant Sciences. Vol. 4 issue 4 pp. 417 421.

Mertz, W. (1972) Human Requirements: Basic and Optimal, Ann. N. Y. Acad. Sci. 199:191.

Miracle Trees, September 2014 , http://miracletrees.org/.

Mohammed, S. A., Folorunsho, J. O., (2015),
Heavy metals concentration in soil and Amaranthusretroflexus grown on irrigated farmlands in the Makera Area, Kaduna, Nigeria. Journal of Geography and Regional Planning. 8(8)pp. 210-217.

Murthy, 1., and Anderson B. M., (1976); The Effect of Dietary Zinc and Copper Interrelationships on Blood Parameters of the Rat. Journal of Agric Food Chemistry.24:808.

Offor I., Ehiri R. and Njoku C., (2014 ); "Proximate nutritional analysis and heavy metal composition of dried Moringa oleifera leaves from OshiriOnicha LGA, Ebonyi State, Nigeria," IOSR Journal of Environmental Science, Toxicology and Food Technology, vol. 8, no. 1, pp. 57-62,.

Oluduro A. O., (2012); "Evaluation of antimicrobial properties and nutritional potentials of Moringa oleifera Lam. leaf in South-Western Nigeria," Malaysian Journal of Microbiology, vol. 8, no. 2, pp. 59-67,

Ross A. C., Taylor C. L., Yaktine A. L. (2011); Institute of Medicine (US) Committee to Review Dietary Reference Intakes for Vitamin D and Calcium; Washington (DC): National Academics Press.

Russell J. L., Campbell J. L., Boyd N. I., Dias J. F. (2018); GUMAP: a GUPIXWINcompatible code for extraction regional spectral from nuclear microbeam list mode files. Nuclear Instrumentation and Method.B417 46-50.

Scoones, I., Melnyk M. and Pretty J.N. (1992); The Hidden Harvest: Wild Foods and Agricultural Systems: A Literature Review and Annotated Bibliography. IIED.Swedish International Development Authority and World Wide Fund for Nature, London and Gland.

Spivey-Fox, M. R. (1972); In: Metallic Contaminants and Human Health, D. H. K. Lee Ed. (New York: Academic Press, Inc., $p 195$.

Yameogo C.W., Bengaly M.D., Savadogo A. (2011). Determination of chemical composition and nutritional values of Moringa oleifera leaves. Pakistan Journal of Nutrition.; 10(3) :264-268. 